\title{
Influence of Rice Rotation Systems on Soil Nematode Trophic Groups in Arkansas
}

\author{
Martin M. Matute (Corresponding author) \\ Department of Biology, University of Arkansas, Pine Bluff, AR 71601, USA \\ Tel: 1-870-575-8851_E-mail: matutem@uapb.edu
}

Merle Anders

Rice Research and Extension Center, Stuttgart, AR 72160, USA

Received: May 26, 2011

Accepted: June 9, $2011 \quad$ Online Published: December 21, 2011

doi:10.5539/jas.v4n2p11

URL: http://dx.doi.org/10.5539/jas.v4n2p11

Sponsor: This research was supported in part by an EPSCoR grant awarded to the senior author

\begin{abstract}
The effects of crop rotation sequences and combinations on soil nematode populations were investigated. Tillage versus non-tillage treatments were applied to crop rotation sequences dominated by flooded rice in a split plot design. The rotated crops were rice, soybean, and corn, including a fallow for a total of eight rotation treatments. All nematode feeding groups were recovered i.e bacterial feeding-, fungal feeding-, plant feeding-, carnivorous-, and omnivorous- nematodes. A total of 24 nematode genera in 20 families were identified and categorized into their respective trophic groups and colonizer persister $(\mathrm{cp})$ values. All rotations that included soybean significantly $(\mathrm{P}<0.05)$ or numerically increased soil nematode populations, irrespective of trophic groups, while all rotations that included rice and corn, had a nematode reductive effect. No-tillage plots recorded significantly higher populations of the predatory nematodes. The effectiveness of a rotation sequence depends primarily on the crop species and secondarily on soil conditions e.g anaerobic.
\end{abstract}

Keywords: Arkansas, Nematodes, Trophic groups, Rice rotations, Tillage, Anaerobic

\section{Introduction}

The success of crop rotations in soil pest suppression is predicated on mixing crop species sequences so as to create varying patterns of resource competition, allelopathic interference, soil disturbance, and mechanical disruptions. These conditions in turn lead to an unstable and frequently inhospitable environment that prevents the proliferation of a particular pest species (Roger et al., 1989). How well a specific rotation might prevent pest species proliferation may or may not be mediated by tillage practices; particularly no-till where plant residues remain on the field. In this investigation, we measured nematode populations in a series of crop rotations (dominated by rice) that were conventional-and no-till managed. Arkansas ranks first among the six major rice-producing states, accounting for approximately 48 percent of the U.S. rice production. Rice production is concentrated in the eastern half of the state, stretching from the Louisiana to the Missouri borders. Arkansas rice is known for its versatility and can be used in a wide variety of cuisines. It is enjoyed in the United States and throughout the world. Rice production is a major backbone to the State's economy.

Aung and Prot ( 1990) reported on the effects of corn, cowpea, mungbean, rice, and sorghum on the population densities of Pratylenchus zeae in upland rice fields in the Philippines, they reported that the three cereal crops were very good nematode hosts, while the two legumes crops were resistant to this parasite. However, they observed that two successive cropping seasons were necessary to reduce nematode population densities to an acceptable low level. Rice grain yield when grown after cowpea and/or mungbean was significantly higher than that obtained after cereal crops. Grain yield of rice following rice was $37 \%$ lower than when it followed cowpea. Aung and Prot (1990) concluded that the control of $P$. zeae by crop rotations using cowpea or mungbean is 
feasible. However, since the surviving nematodes multiply very rapidly on rice, rotating will protect only one rice crop (Aung and Prot, 1990).

In the past, several studies have been devoted to establishing a relationship between soil tillage and cropping patterns effects on soil organisms (Neher, 2001; Ferris and Matute, 2003; Smiley et al., 2004; Adediran et al., 2005; Roberts et al., 2005) and in the case of soil nematodes, the emphasis has been on the plant-parasitic nematode populations. A strong influence of tillage practices and cropping patterns on nematode faunal composition and the soil food web has been reported in a legume-vegetable rotation system in California (Sanchez-Moreno et al., 2006).

Crop rotation sequences that will reduce populations of plant feeding nematodes and increase populations of decomposer nematode guilds are desirable. We investigated the influence of crop rotation sequences on soil nematode populations in the rice agroecology of Stuttgart, Arkansas. Tillage versus non-tillage treatments were applied to crop rotation sequences in a split-plot design. While information on the effects of rotations and tillage on soil nematode populations already exists (Ferris and Matute, 2003; Minoshima et al., 2007; Sanchez-Moreno et al., 2006), this investigation includes specific rotations that are ecologically and economically relevant to rice production in Arkansas. Plant-parasitic nematodes are known to reduce the productivity of rice fields and also certain free-living nematodes are known to increase soil fertility. We were specifically interested in elucidating crops that should not be included in a rice rotation because they increased populations of plant-parasitic nematodes and also to elucidate crops that increased populations of free-living nematodes. Such information will be useful in the rice agroecology zone of Arkansas.

\section{Research Methods}

\subsection{Study Site}

Sampling plots for this field study were located at the University of Arkansas Rice Research and Extension Center, Stuttgart, Arkansas. Soil at the study site is a Dewitt silt loam. This is the prevalent soil type used for rice production in Arkansas. Soil properties measured following preparation of the site and before initial plantings indicate a $\mathrm{pH}$ range of 5.5 and a mean content of $0.71 \mathrm{~g} \mathrm{C} \mathrm{Kg}^{-1}$ soil and $0.07 \mathrm{~g} \mathrm{~N} \mathrm{Kg}^{-1}$ soil. The study site was not previously used for cropping.

\subsection{Experimental Design}

Tillage versus non-tillage treatments were applied to crop rotation sequence in a split plot design. Main plots (76 $\mathrm{m}$ by $12 \mathrm{~m}$ ) consisted of seven crop rotations. The main plots were split into sub-plots based on two tillage treatments (Conventional tillage and no-tillage). Each treatment had four replications. The rotated crops were Oryza sativa (rice), Glycine max (soybean), and Zea mays (corn/maize). The rotation combinations were as outlined in table I and each plot has been grown to three crops. Samples were collected at plant establishment and at harvest during the third rotation or cropping season. Conventional tillage treatments are tilled in the fall and spring as per standard farming practices while the no-till plots are not tilled and all residues remains on the plots. Rice plots were flooded before planting. For the cropping sequences, there were eight $(8)$ rotation combinations designated as R-R-R, S-S-R, R-C-S etc including the control adjacent natural areas devoid of crops (= fallow) designated as F-F-F ( table 1). When samples were collected planting was done between April and June and these crops harvested by October.

\subsection{Soil sampling, nematode extraction and identification}

Initial soil samples were collected in June after all crops have emerged and another set of samples collected from same plots in November, following crop harvest. Soil samples were collected using a $2.5 \mathrm{~cm}$ diameter foot driven soil sampler. Samples were collected to the hardpan depth (approximately $15-22 \mathrm{~cm}$ ). A total of six-core sub-samples were collected and pooled by plot. These composite samples were mixed and nematodes were extracted from a $100 \mathrm{~mL}$ sub-sample using a combination of decanting, sieving and Baermann funnels methods (Barker, 1985). Nematodes were harvested after 72 hours. The first $15 \mathrm{~mL}$ were collected from each sample and all the nematodes counted at low magnification, and then at least 100 nematodes from each sample were identified to genus or family level at higher magnification (Ferris and Matute, 2003) and then adjusted to the total nematode count per sample. Nematodes recovered were categorized according to their trophic groups, families, genera, and colonizer persister (cp) classes (Yeates et al., 1993).

\subsection{Statistical Analyses}

The parameters tested for statistically significant differences $(\mathrm{P}<0.05)$ on nematode categories included, rotation(R), tillage (T), sampling time (ST), and the interactions $\mathrm{R} \times \mathrm{T}, \mathrm{R} \times \mathrm{ST}, \mathrm{T} \times \mathrm{ST}$, and $\mathrm{R} \times \mathrm{T} \times \mathrm{ST}$. The statistical analyses were completed using SYSTAT 12 GLM procedure. Time of sampling was included in the 
ANOVA in order to determine changes within each nematode feeding group attributable to rotation and /or tillage. A Turkey test at a $\mathrm{P}<0.05$ level was used to separate treatment means.

\section{Results}

All nematode feeding guilds or groups were recovered i.e bacterial feeding-, fungal feeding-, plant feeding-, carnivorous-, and omnivorous- nematodes. A total of 24 nematode genera in 20 families were identified and categorized into their trophic groups and colonizer persister values (table 2). Trophic groups describe nematode feeding habits for example Prismatolaimus is a bacterial feeder $(=\mathrm{Ba})$, Helicotylenchus is a plant feeder or plant parasite $(=\mathrm{Pl})$, and Mylonchulus is a carnivore or predator $(=\mathrm{Ca})$. Additionally, $\mathrm{cp}$ values (Bongers and Bongers, 1998) are numerical values that describe the size, length of life course, sensitivity to environmental perturbation, etc. For example, cp1 represents a small sized nematode with a very fast reproductive rate and it is not sensitive to environmental perturbation, while $\mathrm{cp} 5$ represents a large bodied nematode, with a slow reproductive rate, and is very sensitive to environmental disturbances.

\subsection{Bacterivorous Nematodes (Ba)}

There was no significant difference $(\mathrm{P}<0.05)$ in bacterivorous nematode populations between tillage treatments (table 3). There was a significant interaction $(\mathrm{P}=0.032)$ between $\mathrm{ST} \times \mathrm{R}$, while all other interactions did not have a significant effect on these nematodes. Higher numbers of these nematodes were recovered during plant establishment as compared to harvest and in no-tillage plots as compared to conventional tillage, though these differences were not significant. In general all rotations that included soybeans recorded higher populations of these nematodes as compared to rotations that excluded soybeans. On the other hand lowest numbers of these nematodes were associated with R-R-C and C-C-R treatments.

\subsection{Fungivorous Nematodes (Fu)}

Populations of fungivorous nematodes were significantly affected by ST, R, and the interactions ST x T and ST $\mathrm{x}$ R x T (table 4). Populations of these nematodes were higher during plant establishment as compared to harvest time $(\mathrm{P}=0.021)$. Also rotation sequences that included soybean and rice e.g R-C-S, S-S-R, R-R-S, recorded significantly higher populations of these nematodes $(\mathrm{P}=0.035)$ as compared to rotations that included rice and corn e.g R-R-C and C-C-R. In addition the interactions ST $x$ R and ST $x$ R $x$ T, significantly affected populations of these nematodes. It is noted that all treatments except the fallow included rice. Our data in table 4 shows that the treatment F-F-F recorded the highest number of fungivorous nematodes. This seems to suggest that rice has a proliferative effect on fungivorous nematodes. Tillage had no significant effect on these nematodes though the conventional-tillage plots recorded higher populations. We attribute this to the fact that conventional-till treatments were tilled in the fall thus organic crop residues were incorporated into the soil and, with winter rains, this enhanced fungal decomposition activities. Crop residues were not incorporated into the soil for the no-till treatments thus they remained on the soil surface where they dried out. These results do not support earlier literature showing that no-till results in higher fungivorous nematodes as compared to tillage regimes where crop residues are incorporated into the soil. Our data seems to suggest that organic matter left on the soil surface might not be an ideal environment for fungal decomposition (quick drying) thus fewer fungivorous nematodes.

\subsection{Plant parasitic Nematodes (Pl)}

Plant-parasitic nematodes are most often studied because of their ability to reduce crop yields. In this study plant-parasitic nematode populations were very highly significantly $(\mathrm{P}<0.001)$ affected by rotation (table 5$)$. There was a highly significant $(\mathrm{P}<0.01)$ interaction of ST $\mathrm{x}$ R on populations of these nematodes. Overall plant-parasitic nematode numbers were lowest in the R-R-R rotation treatment indicating that parasitic nematodes specific to rice growing conditions (anaerobic) and parasitic to rice are yet to establish high population densities in these fields. Nematode populations were highest following crop harvest for the F-F-F, R-R-S, R-C-S, and R-S-C rotations. For the most part, rotation sequences that included soybean, favored higher populations of the parasitic nematodes, while the R-R-R and R-R-C rotations significantly reduced the populations of these herbivorous nematodes $(\mathrm{P}<0.0005)$ (table 5). Continuous rice $(\mathrm{R}-\mathrm{R}-\mathrm{R})$ was the most effective in reducing plant-parasitic nematodes with nematode numbers as low as 16 nematodes $100 \mathrm{~mL}^{-1}$ soils.

\subsection{Omnivorous Nematodes (Om)}

Of all the variables measured, only tillage had a significant affect $(\mathrm{P}=0.03)$ on the populations of the omnivorous nematodes (table 6). The no-till plots had higher populations of this nematode trophic group when compared to the conventionally tilled plots. Although no statistically significant difference was found for the effect of rotation on the omnivore nematode populations, table 6 shows that all crop rotations reduced populations of these nematodes when compared to the fallow treatment (F-F-F). The exception was the R-C-S rotation that supported 
more of these nematodes than the fallow. Among the rotation combinations, R-R-R, R-C-S and R-S-C, recorded the highest numbers of these nematodes.

\subsection{Carnivorous or Predatory Nematodes (Ca)}

Unlike the previous nematode trophic groups already listed above, carnivorous nematode numbers were not significantly different for any of the main effects (table 7). Only the ST x T interaction had a significant $(\mathrm{P}<0.005)$ effect on the populations of the carnivorous nematodes. Predatory nematode numbers were greater in the no-till plots regardless of when samples were collected. There was a significant decrease in nematode numbers for both tillage treatments in the later sampling but no significant difference in the tillage treatments in the same sampling time. These results represent a pooling of all rotation effects and suggest that predatory nematode populations increase between growing seasons and decrease during the growing season regardless of the crop grown. This off-season increase is attributed to a soil surface that is protected by crop residue and higher organic matter levels in no-till plots.

\subsection{Total Nematode Abundance (N)}

Pooling counts from all nematode families recovered resulted in no significant $(\mathrm{P}<0.05)$ differences in $\mathrm{ST}$ or $\mathrm{T}$ (table 8). The main effect of rotation was significantly different $(\mathrm{P}=0.029)$ along with $\mathrm{ST} \times \mathrm{T}$ interaction. This finding is consistent with previous data reported for the respective nematode trophic groups i.e bacterial feeders, fungal feeders, plant-parasitic, omnivores, and predatory nematodes.

Summary: All rotations that included G. max significantly $(\mathrm{P}<0.05)$ or numerically increased soil nematode populations, irrespective of trophic groups, while all rotations that included $O$. sativa and Z. mays, had a nematode reductive effect. For example, there were 428 bacterivorous nematodes per $100 \mathrm{~mL}$ soil in the R-C-S rotation compared to the 336 nematodes $/ 100 \mathrm{~mL}$ soil for the $\mathrm{R}-\mathrm{R}-\mathrm{R}(\mathrm{P}=0.06)$. Similarly, for the plant feeders the rotation combination R-C-S recorded 140 nematodes per $100 \mathrm{~mL}$ soil compared to 16 nematodes per $100 \mathrm{~mL}$ soil for the R-R-R combination $(\mathrm{P}<0.001)$. These data indicate that rice and corn are not suitable hosts to the nematodes recovered in this study. The relative contributions of the bacterivore, fungivore, herbivore, omnivore, and carnivore nematode guilds to total nematode numbers was $42.1,42.1,9.5,5.6$, and 0.7 percent respectively.

\section{Discussion}

In our study all five nematode trophic groups (bacterivores, fungivores, plant-parasites or herbivores, omnivores, and carnivores or predators) were recovered. Consistently, all rotation treatments containing soybean provided a conducive environment for the proliferation of these nematodes. Accordingly, all rotations with a soybean component had significantly or numerically higher nematode populations than rotations excluding soybean. In a previous study, Ferris and Matute (2003) reported that cumulative amounts of $\mathrm{N}$ mineralization in field plots was directly related to the nematode Enrichment Index (EI) which is based on the abundance of opportunistic bacterial- and fungal-feeding nematodes. Fungi- and bacterial-feeding nematodes and other organisms that graze on primary decomposers accelerate the decomposition of soil organic matter and increase mineralization, thus releasing nutrients for plant growth (Chen and Ferris, 1999; Akhtar and Malik, 2000; Neher, 2001; Ferris and Matute, 2003). In our investigation, the bacterial and fungal feeding nematodes constituted over 85 percent of total nematode numbers.

With the exception of omnivorous nematodes, there was no significant difference between convention- and no-till fields in their bacterivorous, fungivorous, plant-parasitic, and carnivorous nematode populations. Previously, it was reported that bacterial-feeding nematodes were stimulated by tillage and were dominant in tilled plots (Wardle, 1995; Lenz and Eisenbeis, 2000). However, in our investigation bacterial-feeding nematode populations were slightly higher in no-till plots when compared to tilled plots. A probable explanation for this apparent discrepancy is attributed to the fact that our rotation study included soybean that created a hospitable microenvironment for the proliferation of these nematodes regardless of tillage or intact soils. In our investigation, a hospitable or conducive environment was one that contains lots of decomposing plant residue as was the case with the no-till as compared to the conventional till.

Our investigation concludes that rotations including soybean resulted in significantly or numerically higher nematode populations irrespective of trophic groups and also that no-till fields did not necessarily result in increased nematode populations as would have been expected (Nakamoto et al., 2006). It is possible that the inclusion of rice (a flooded crop) disrupts the habitat to such an extent that nematode numbers do not follow trends reported in studies that do not contain a flooded crop. With rice, we do not only change the available food source but the field is anaerobic which results in habitat changes. 
Omnivorous nematode numbers were significantly higher in no-till plots when compared to conventional-till plots. The positive effects of limiting physical disturbance may include increases in the abundance of nematode fauna (Kakamoto et al., 2006). Most organisms are more abundant in no-till than in conventional-till systems and larger-bodied organisms are especially sensitive to soil disruption (Kladivko, 2001). The omnivorous nematodes recovered in this study included Mesodorylaimus, Eudorylaimus and Thornenema. These nematodes have colonizer-persister (cp) values of cp4 and cp5 respectively. These values place them in the larger-bodied nematode category and thus would be expected to be less prevalent in soils that are disturbed or conventionally-tilled. Our results therefore corroborate earlier reports.

Plant-parasitic nematodes are a leading biotic cause of plant yield reduction (second only to drought) (Opperman and Bird, 2001). World-wide, 10 percent of annual rice production is lost due to plant-parasitic nematodes (Sasser and Freckman, 1987) and up to 50-90 percent in parts of Asia (Hashioka, 1963). An abundance of plant parasitic nematodes in rice plots will therefore be an indication of poor soil health, poor plant growth, and poor grain yield. In our study, rotations containing a rice or corn phase significantly reduced parasitic nematode populations, especially in the continuous rice rotation. In a crop rotation study by Aung and Prot (1990), they reported that grain yield of rice following rice was 37\% lower than when it followed cowpea. Aung and Prot (1990) concluded that the control of Pratylenchus zeae (plant-parasitic nematode) by crop rotations using cowpea or mungbean was feasible. However, in our investigation we found that the continuous rice rotation treatment (R-R-R) was the most effective in keeping rice parasitic nematode populations at very low levels (16 nematodes $100 \mathrm{~mL}^{-1}$ soil). In the Stuttgart Arkansas area there are rice fields that have been under continuous rice production for up to 50 years and they are still very productive. This suggests that continuous rice cropping does not necessary lead to a build-up of rice parasitic nematodes but rather seems to have a suppressive effect on their population densities. However, a reduction in these root-feeders and an increase in the populations of the decomposer guilds (bacterivores and fungivores) will be ideal for maintaining healthy soils and improving soil fertility.

Overall higher fungivorous nematode numbers at plant establishment as compared to following harvest suggests that plots that are flooded (anaerobic) do not promote high populations of these nematodes. Flooding and soil fumigation effectively control several diseases and weeds and are harmful to many other soil organisms (van Os et al., 2008). In a study to investigate the effects of flooding and non-flooding on Earthworm communities, Ivask et al. (2006) reported that flooded plots had less species diversity when compared to non-flooded plots. Our results corroborate these earlier reports in that we had lower fungal-feeding nematode populations in flooded or previously flooded plots.

Depending on the component crops in a rotation, rotations may either result in an increase in the abundance of soil nematodes or a decrease. In our study we note that rice and corn rotations have a nematode population suppressive effect while on the other hand soybean rotations have a nematode population proliferative effect. We also note that an additional factor to rotation combination is management practice. Thus continuous rice plots that were flooded created anaerobic conditions that were very effective in the suppression of nematode populations, especially the plant-parasitic nematodes.

There have been numerous studies that have attempted to make a direct correlation between soil nematode numeric abundance and conventional-tillage and/or intact soils. For example the studies by Wardle (1995), Bulluck et al. (2002), Liphadzi (2005), Lenz and Eisenbeis (2000), Ferris and Matute (2003), and many others. The only consistency in such studies is the establishment of a direct relationship between large-bodied nematodes particularly predators and no-till soils i.e predatory nematodes are absent or significantly reduced in disturbed soils. For all other nematode trophic groups, varied results have been reported. From our results, it seems the crop type and the respiratory conditions of the soil are the primary and secondary determinants respectively of nematode suppressivity or proliferation as opposed to tillage and intact soils. Thus soybean containing rotations promote nematode proliferation as compared to rotations without soybean and flooded anaerobic conditions were suppressive to nematode population density build-up.

The Stuttgart agroecology zone is the major rice production area of Arkansas. Rice, Corn and Soybean are the major crops grown, often in rotation. Our investigation concludes that rice plots should exclude soybeans in a rotation because they create a microenvironment conducive for the proliferation of plant-parasitic nematodes that could lead to low rice yield. However, considering that soybeans significantly increases the populations of bacterivorous and fungivorous nematodes associated with soil fertility, the decision to use or not to use soybean in a rice rotation therefore, may need further study from a yield perspective. 


\section{Acknowledgements}

This paper was supported in part by an EPSCoR grant awarded to the senior author. We are also grateful to Dr. R.T. Robins of the University of Arkansas-Fayetteville for providing guidance throughout this preliminary investigation.

\section{References}

Adediran, J.A., Adegbite, A.A., Akinlosotu, T.A., Agbaje, G.O., Taiwo, L.B., Owolade, O.F. \& Oluwatosin, G.A. (2005). Evaluation of fallow and cover crops for nematode suppression in three agroecologies of south western Nigeria. African Journal of Biotechnology, 4, 1034-1039.

Akhtar, M \& Malik, A. (2000). Roles of organic soil amendments and soil organisms in the biological control of $\begin{array}{llllll}\text { plant-parasitic nematodes } \quad \text { (a review). } & \text { Biores. } & \text { Technol., } & \text { 74, }\end{array}$ http://dx.doi.org/10.1016/S0960-8524(99)00154-6

Aung, T. \& Prot, J. C. (1990). Effects of crop rotation on Pratylenchus zeae and on yield of cultivar UPLRi-5. Revue Nematol., 13 (4), 445- 447.

Barker, K.R. (1985). Nematode extraction and bioassays. In: Barker, K.R., Carter, C.C., Sasser, J.N. ( Eds), An Advanced Treatise on Meloidogyne: Methodology, Vol. 2. North Carolina State University Graphics, Raleigh, 19-35.

Bulluck III, L.R., Barker, K.R. \& Ristaino, J.B. (2002). Influences of organic and synthetic soil fertility amendments on nematode trophic groups and community dynamics under tomatoes. Applied Soil Ecology, 21, 233-250. http://dx.doi.org/10.1016/S0929-1393(02)00089-6

Chen, J \& Ferris, H. (1999). The effects of nematode grazing on nitrogen mineralization during fungal decomposition of organic matter. Soil Biol. Biochem., 31, 1265-1279. http://dx.doi.org/10.1016/S0038-0717(99)00042-5

Ferris, H. \& Matute, M. M. (2003). Structural and functional succession in the nematode fauna of a soil food web. Applied Soil Ecology, 23, 93-110. http://dx.doi.org/10.1016/S0929-1393(03)00044-1

Hashioka, Y. (1963).The rice stem nematode Ditylenchus angustus in Thailand. Plant Protection Bulletin. F.A.O. 11, 97-102.

Ivask, M., J. Truu, A. Kuu, M. Truu, \& Leito, A. 2006. Earthworm communities of flooded grasslands in Matsahy, Estonia. European Journal of Soil Biology, Vol. 43(2), 71-76. http://dx.doi.org/10.1016/j.ejsobi.2006.09.009

Kladivco, E. J. (2001). Tillage systems and soil ecology. Soil and Tillage Research, 61, 61-76. http://dx.doi.org/10.1016/S0167-1987(01)00179-9

Lenz, R. \& Eisenbeis, G. (2000). Short-term effects of different tillage in a sustainable farming system on nematode community structure. Biology and Fertility of Soils, 31, 237-244. http://dx.doi.org/10.1007/s003740050651

Liphadzi, K.B., Al-Khatib, K., Bensch, C., Stahlman, P.W., Dille, J.A., Todd, T., Rice, C.W., Horak, M. J. \& Head, G. (2005). Soil microbial and nematode communities as affected by glyphosate and tillage practices in a glyphosate-resistant cropping system. Weed Science, 53, 536-545. http://dx.doi.org/10.1614/WS-04-129R1

Minoshima, H., Jackson, L. E., Cavagnaro, T. R., Sanchez-Moreno, S., Ferris, H., Temple, S. \& Mitchell, J. (2007). Soil food webs and carbon dynamics in response to conservation tillage in legume rotations in California. Soil Science Society of America Journal, 71, 952-963. http://dx.doi.org/10.2136/sssaj2006.0174

Nakamoto, T., Yamagishi, J. \& Miura, F. (2006). Effect of reduced tillage on weeds and soil organisms in winter wheat and summer maize cropping on humic andosols in Central Japan. Soil and Tillage Research, 85, 94-106. http://dx.doi.org/10.1016/j.still.2004.12.004

Neher, D. (2001). Role of nematodes in soil health and their use as indicators. Journal of Nematology, 33, 161-168.

Opperman, C \& Bird, D. (2001). Bioengineering applied in nematology. XXIII Meeting of the Brazilian Society of Nematology, March 2001, Brazil.

Roberts, P.A., Matthews, W.C. \& Ehlers, J.D. (2005). Root-knot nematode resistant cowpea cover crops in tomato production systems. Agronomy Journal, 97, 1626-1635. http://dx.doi.org/10.2134/agronj2004.0290 
Roger, P.A., Heong, K.L. \& Teng, P.S. (1989). Biodiversity and sustainability of wetland rice production: Role and potential of microorganisms and invertebrates. International Rice Research Institute-IRRI Strategy, 1990-2000 and Beyond. IRRI, Manila, Phillipines.

Sánchez-Moreno, S., Minoshima, H., Ferris, H. \& Jackson, L.E. (2006). Linking soil properties and nematode community composition: effects of soil management on soil food webs. Nematology, 8(5), 703-715. http://dx.doi.org/10.1163/156854106778877857

Sasser, J. N. \& Freckman, D.W. (1987). World perspective on nematology: the role of the society. In Vistas on Nematology: a Commemoration of the Twenty-fifth Anniversary of the Society of Nematologists. J.A. Veech and D.W.Dickson, eds. Society of Nematologists, Inc. Hyattville, MD. 7-14.

Smiley, R.W., Merrifield, K., Patterson, L.M., Whittaker, R.G., Gourlie, J.A. \& Easley, S.A. (2004). Nematodes in dryland field crops in the semiarid Pacific Northwestern United States. Journal of Nematology, 36, 54-68.

Van Os, G.J., van Gulik, W.J.M., Wijnker, J.P.M. (2008). Effects of flooding, soil fumigation, and composted organic household waste on Pythium root rot in Bulbous Iris. Acta Horticulturae 430: $7^{\text {th }}$ International Symposium on Flowerbeds.

Wardle, D. A. (1995). Impacts of disturbance on detritus food webs in agro-ecosystems of contrasting tillage and weed management practices. In: Begon, M and Fitter, A. H. (Eds). Advances in Ecological Research, Vol. 26. New York, NY, USA, Academic Press, 105-185.

Yeates, G. W., Bongers, T., De Goede, R. G. M., Freckman, D. W \& Georgieva, S. S. (1993). Feeding-habits in soil nematode families and genera-an outline for soil ecologists. Journal of Nematology, 25, 315-331.

Table 1. Crops, rotation combinations, rotation sequences and designation of rotation treatments

\begin{tabular}{|l|l|l|l|l|}
\hline Crops/Treatment & Rotation 1 & Rotation 2 & Rotation 3 & Rotation Designation \\
\hline Fallow & Fallow & Fallow & Fallow & F-F-F \\
\hline Rice & Rice & Rice & Rice & R-R-R \\
\hline Rice, Soybean & Rice & Rice & Soybean & R-R-S \\
\hline Soybean, Rice & Soybean & Soybean & Rice & S-S-R \\
\hline Rice, Corn & Rice & Rice & Corn & R-R-C \\
\hline Corn, Rice & Corn & Corn & Rice & C-C-R \\
\hline Rice, Corn, Soybean & Rice & Corn & Soybean & R-C-S \\
\hline Rice, Soybean, Corn & Rice & Soybean & Corn & R-S-C \\
\hline
\end{tabular}

Table 2. Trophic guilds, families, genera, and $\mathrm{cp}$ values for nematodes recovered from one fallow and seven rotations that were sampled following plant establishment and following harvest

\begin{tabular}{|c|c|c|c|}
\hline Trophic Guilds & Families & Genera & $\begin{array}{l}\text { cp } \\
\text { values }\end{array}$ \\
\hline \multirow[t]{3}{*}{ Bacterial Feeders } & Rhabditidae, Panagrolaimidae & $\begin{array}{l}\text { Rhabditis, Mesorhabditis, } \\
\text { Poikilolaimus, Panagrolaimus }\end{array}$ & $\mathrm{Ba}_{1}$ \\
\hline & Cephalobidae, Plectidae & Acrobeloides, Cephalobus, Plectus & $\mathrm{Ba}_{2}$ \\
\hline & Prismatolaimidae & Prismatolaimus & $\mathrm{Ba}_{3}$ \\
\hline Fungal Feeders & Aphelenchoididae, Aphelenchidae & Aphelenchoides, Aphelenchus & $\mathrm{Fu}_{2}$ \\
\hline \multirow[t]{4}{*}{$\begin{array}{l}\text { Plant Feeders or Plant } \\
\text { parasites }\end{array}$} & $\begin{array}{l}\text { Tylenchidae, Psilenchidae, } \\
\text { Paratylenchidae }\end{array}$ & $\begin{array}{l}\text { Tylenchus, Psilenchus, } \\
\text { Paratylenchus }\end{array}$ & $\mathrm{Pl}_{2}$ \\
\hline & $\begin{array}{l}\text { Belonolaimidae, Pratylenchidae, } \\
\text { Heteroderidae, Hoplolaimidae }\end{array}$ & $\begin{array}{l}\text { Tylenchorhyncus, Pratylenchus, } \\
\text { Heterodera, Helicotylenchus }\end{array}$ & $\mathrm{Pl}_{3}$ \\
\hline & Trichodoridae & Paratrichodorus & $\mathrm{Pl}_{4}$ \\
\hline & Longidoridae & Xiphinema & $\mathrm{Pl}_{5}$ \\
\hline $\begin{array}{l}\text { Carnivorous } \\
\text { nematodes or } \\
\text { predators }\end{array}$ & Mononchidae & Mylonchulus, Mononchus & $\mathrm{Ca}_{4}$ \\
\hline \multirow{2}{*}{$\begin{array}{l}\text { Omnivorous } \\
\text { nematodes }\end{array}$} & Dorylaimidae, Qudsianematidae & Mesodorylaimus, Labronema & $\mathrm{Om}_{4}$ \\
\hline & Thornenematidae & Thornenema & $\mathrm{Om}_{5}$ \\
\hline
\end{tabular}

Symbols are $\mathrm{Ba}=$ Bacterivore, $\mathrm{Fu}=$ Fungivore, $\mathrm{Pl}=$ Plant feeder or plant parasite, $\mathrm{Ca}=\mathrm{Carnivore}$ or Predator, $\mathrm{Om}=$ Omnivore, $\mathrm{cp}=$ colonizer-persister $(\mathrm{cp})$ value 
Table 3. Summary of ANOVA main effects, probability values, and main effect treatment mean square values for Bacterivorous nematode numbers in $100 \mathrm{ml}$ soil samples collected at plant establishment and following harvest from one fallow and seven rotation plots

\begin{tabular}{|l|l|l|}
\hline \multicolumn{1}{|c|}{ Variable } & P-value & \multicolumn{1}{c|}{ Value } \\
\hline Sample Time (ST) & 0.2594 & $\begin{array}{l}\text { Harvest }=295 \\
\text { Plant establishment }=356\end{array}$ \\
\hline Rotation (R) & 0.0601 & $\begin{array}{l}\text { F-F-F }=280 \\
\text { R-R-R }=336 \\
\text { R-R-S }=351 \\
\text { S-S-R }=330 \\
\text { R-R-C }=237 \\
\text { C-C-R }=275 \\
\text { R-C-S }=428 \\
\text { R-S-C }=366\end{array}$ \\
& & $\begin{array}{l}\text { Conventional }=320 \\
\text { No-till }=330\end{array}$ \\
\hline Tillage (T) & 0.9035 & \\
\hline $\begin{array}{l}\text { ST x R } \\
\text { R x T } \\
\text { ST x T }\end{array}$ & 0.0325 & 0.4103 \\
ST x R x T & 0.1322 & \\
\hline
\end{tabular}

Symbols are $\mathrm{R}=$ rice, $\mathrm{S}=$ soybeans, $\mathrm{C}=$ corn, $\mathrm{F}=$ fallow.

Table 4. Summary of ANOVA main effects, probability values, and main effect treatment mean square values for Fungivorous nematode numbers in $100 \mathrm{ml}$ soil samples collected at plant establishment and following harvest from one fallow and seven rotation plots

\begin{tabular}{|c|c|c|}
\hline Variable & $P$-value & Value \\
\hline Sample Time ( ST) & 0.0210 & $\begin{array}{l}\text { Harvest }=290 \\
\text { Plant establishment }=428\end{array}$ \\
\hline Rotation ( R) & 0.0359 & $\begin{array}{l}\text { F-F-F }=552 \\
\text { R-R-R }=260 \\
\text { R-R-S }=400 \\
\text { S-S-R }=421 \\
\text { R-R-C }=281 \\
\text { C-C-R }=255 \\
\text { R-C-S }=457 \\
\text { R-S-C }=249\end{array}$ \\
\hline Tillage ( T) & 0.7005 & $\begin{array}{l}\text { Conventional }=376 \\
\text { No-till } 342\end{array}$ \\
\hline $\begin{array}{l}\text { ST } x \mathrm{R} \\
\mathrm{R} \times \mathrm{T}\end{array}$ & $\begin{array}{l}0.0102 \\
0.0586\end{array}$ & \\
\hline ST x T & 0.9373 & \\
\hline ST x R x T & 0.0268 & \\
\hline
\end{tabular}

Symbols are $\mathrm{R}=$ rice, $\mathrm{S}=$ soybeans, $\mathrm{C}=$ corn, $\mathrm{F}=$ fallow. 
Table 5. Summary of ANOVA main effects, probability values, and main effect treatment mean square values for Plant-parasitic nematode numbers in $100 \mathrm{ml}$ soil samples collected at plant establishment and following harvest from one fallow and seven rotation plots

\begin{tabular}{|c|c|c|}
\hline Variable & $P$-value & Value \\
\hline Sample Time ( ST) & 0.0629 & $\begin{array}{l}\text { Harvest }=129 \\
\text { Plant establishment }=46\end{array}$ \\
\hline Rotation ( $\mathrm{R}$ ) & 0.0005 & $\begin{array}{l}\text { F-F-F }=175 \\
\text { R-R-R }=16 \\
\text { R-R-S }=109 \\
\text { S-S-R }=71 \\
\text { R-R-C }=35 \\
\text { C-C-R }=63 \\
\text { R-C-S }=140 \\
\text { R-S-C }=90\end{array}$ \\
\hline Tillage ( T) & 0.7005 & $\begin{array}{l}\text { Conventional }=82 \\
\text { No-till }=93\end{array}$ \\
\hline $\begin{array}{l}\text { ST x R } \\
\mathrm{R} \times \mathrm{T}\end{array}$ & $\begin{array}{l}0.0013 \\
0.6242\end{array}$ & \\
\hline ST $\times$ T & 0.9882 & \\
\hline ST $x \mathrm{R} \times \mathrm{T}$ & 0.7909 & \\
\hline
\end{tabular}

Symbols are $\mathrm{R}=$ rice, $\mathrm{S}=$ soybeans, $\mathrm{C}=$ corn, $\mathrm{F}=$ fallow.

Table 6. Summary of ANOVA main effects, probability values, and main effect treatment mean square values for Omnivorous nematode numbers in $100 \mathrm{ml}$ soil samples collected at plant establishment and following harvest from one fallow and seven rotation plots

\begin{tabular}{|c|c|c|}
\hline Variable & $P$-value & Value \\
\hline Sample Time ( ST) & 0.1684 & $\begin{array}{l}\text { Harvest }=29 \\
\text { Plant establishment }=63\end{array}$ \\
\hline Rotation (R) & 0.7488 & $\begin{array}{l}\text { F-F-F }=59 \\
\text { R-R-R }=55 \\
\text { R-R-S }=26 \\
\text { S-S-R }=40 \\
\text { R-R-C }=38 \\
\text { C-C-R }=30 \\
\text { R-C-S }=64 \\
\text { R-S-C }=55\end{array}$ \\
\hline Tillage $(\mathrm{T})$ & 0.0267 & $\begin{array}{l}\text { Conventional }=34 \\
\text { No-till }=58\end{array}$ \\
\hline $\begin{array}{l}\text { ST x R } \\
\text { R x T }\end{array}$ & $\begin{array}{l}0.4640 \\
0.1528\end{array}$ & \\
\hline ST $x$ T & 0.8096 & \\
\hline ST $x \mathrm{R} \times \mathrm{T}$ & 0.2644 & \\
\hline
\end{tabular}

Symbols are $\mathrm{R}=$ rice, $\mathrm{S}=$ soybeans, $\mathrm{C}=$ corn, $\mathrm{F}=$ fallow. 
Table 7. Summary of ANOVA main effects, probability values, and main effect treatment mean square values for Carnivorous nematode numbers in $100 \mathrm{ml}$ soil samples collected at plant establishment and following harvest from one fallow and seven rotation plots

\begin{tabular}{|l|l|l|}
\hline \multicolumn{1}{|c|}{ Variable } & P-value & \multicolumn{1}{|c|}{ Value } \\
\hline Sample Time ( ST) & 0.1350 & $\begin{array}{l}\text { Harvest }=12 \\
\text { Plant establishment }=0\end{array}$ \\
\hline & & $\begin{array}{l}\text { F-F-F }=10 \\
\text { R-R-R }=5 \\
\text { R-R-S }=4 \\
\text { S-S-R }=11 \\
\text { R-R-C }=4 \\
\text { Rotation ( R) }\end{array}$ \\
& $0.2612=4$ \\
& & $\begin{array}{l}\text { R-C-S }=5 \\
\text { R-S-C }=3\end{array}$ \\
& 0.2083 & $\begin{array}{l}\text { Conventional }=3 \\
\text { No-till }=9\end{array}$ \\
\hline Tillage ( T) & 0.2540 & \\
\hline ST x R & 0.1065 & \\
R x T & 0.0052 & \\
ST x T & 0.1088 & \\
ST x R x T & & \\
\hline
\end{tabular}

Symbols are $\mathrm{R}=$ rice, $\mathrm{S}=$ soybeans, $\mathrm{C}=$ corn, $\mathrm{F}=$ fallow.

Table 8. Summary of ANOVA main effects, probability values, and main effect treatment mean square values for Total nematode numbers in $100 \mathrm{ml}$ soil samples collected at plant establishment and following harvest from one fallow and seven rotation plots

\begin{tabular}{|l|l|l|}
\hline \multicolumn{1}{|c|}{ Variable } & P-value & \multicolumn{1}{c|}{ Value } \\
\hline Sample Time ( ST) & 0.5750 & $\begin{array}{l}\text { Harvest }=838 \\
\text { Plant establishment }=810\end{array}$ \\
\hline Rotation ( R) & 0.0292 & $\begin{array}{l}\text { F-F-F }=1077 \\
\text { R-R-R }=672 \\
\text { R-R-S }=890 \\
\text { S-S-R }=874 \\
\text { R-R-C }=595 \\
\text { C-C-R }=627 \\
\text { R-C-S }=1095 \\
\text { R-S-C }=763\end{array}$ \\
\hline Tillage ( T) & 0.9341 & $\begin{array}{l}\text { Conventional }=815 \\
\text { No-till }=833\end{array}$ \\
\hline ST x R & 0.0092 & \\
R x T & 0.2120 & \\
ST x T & 0.5423 & \\
ST x R x T & 0.3827 & \\
\hline
\end{tabular}

Symbols are $\mathrm{R}=$ rice, $\mathrm{S}=$ soybeans, $\mathrm{C}=$ corn, $\mathrm{F}=$ fallow . 